\title{
ARCHITECTURE EDUCATION FOR WORLD CITIZENSHIP
}

Massimo Santanicchia, Associate Professor, massimo@lhi.is

Iceland University of the Arts IUA, School of Architecture, Reykjavik, Iceland

Ph.D. Candidate at the University of Iceland in Culture Studies and Education

\begin{abstract}
Note: This item is a pre-print.

This paper presents findings from fourteen qualitative interviews conducted with students of architecture from eleven schools of the Nordic Baltic Academy of Architecture (NBAA) and from numerous conversations conducted with students in architecture at my home institution: The Iceland University of the Arts (IUA). The findings of these conversations reveal that students consider a meaningful architectural education one that helps them making ethical design choices. To do so respondents indicate that schools should help students find their inner compass, develop their professional skills, and ethical attitudes to think independently and make a difference in their society and beyond. Four narratives emerge which describe the multiple roles of an architect in our society: the dissident intellectual, the ethical professional, the storyteller, and the carer of the world. On the basis of these findings and with the support of the work of Henry Giroux "Critical Theory and Rationality in Citizenship Education" and Martha Nussbaum "Patriotism and Cosmopolitanism", a framework referred to as "Cosmopolitan Citizenship Architecture Education" (CCAE) is developed.
\end{abstract}

Keywords: Architectural education, Citizenship, Cosmopolitan 


\section{INTRODUCTION}

This paper is the result of many conversations conducted with fourteen students in architecture across the Nordic Baltic Academy of Architecture NBAA and with students in architecture at my home institution the Iceland University of the Arts IUA where I am associate professor and program director in Architecture. The NBAA network is composed of sixteen schools of architecture :

Denmark: AArch Aarhus School of Architecture, KADK Royal Danish Academy of Fine Arts

Estonia: EKA Estonia Academy of the Arts

Finland: Aalto University, TUNI Tampere University-Tampere University of Applied Sciences, University of Oulu

Iceland: IUA Iceland University of the Arts,

Latvia: RTU Riga Technical University, Lithuania: VDA Vilnius Academy of the Arts, VGTU Vilnius Gediminas Technical University,

Norway: BAS Bergen School of Architecture, NTNU Norwegian University of Science and Technology, AHO Oslo School of Architecture and Design,

Sweden: Chalmers School of Architecture and Design, KTH The Royal Institute of Technology, Umea School of Architecture.

My intention with this paper is to report students' voices conversing and reflecting together about something that is essential to teachers and students: the education of an architect, and possibly to find valid answers to the question of: how does a good architectural education look like? On the basis of these findings the work of Henry Giroux "Critical Theory and Rationality in Citizenship Education" and Martha Nussbaum "Patriotism and Cosmopolitanism", are then used to formulate a framework referred to as "Cosmopolitan Citizenship Architecture Education" (CCAE).

\section{THEORETICAL CONTEXT}

In 2016 an inspiring book edited by Elizabeth Resnick titled Developing Citizen Designers gave me the possibility to reflect deeply on the value of citizenship in the education of an architect. Resnick opens the book referring to the words of designer Milton Glaser: "good design is good citizenship" (Resnick 2016, 12) and by stating that designers have the moral responsibility to use their skills to address the on-going social and ecological crisis. Developing Citizen Designers not only encourages educators and students to embrace the notion of citizenship in design education but also provides numerous case studies that illustrate a design pedagogy capable of developing social awareness and prompt action. This reinforced my belief that architecture has a strong societal role that goes beyond forms' experimentation and as such it is the duty of architectural educators to empower students to act as world citizens who can act in the interest of the entire ecosystem to which they belong. My interest on citizenship led me to the work of philosopher Martha Nussbaum 
"Patriotism and Cosmopolitanism" and educator Henry Giroux: "Critical Theory and Rationality in Citizenship Education".

Martha Nussbaum defines a cosmopolitan citizen as "the person whose allegiance is to the worldwide community of human beings" (Nussbaum 2010,154). A citizen of the world is a person with a unique identity, strong local bonds and acute awareness of the state of the world: of its problems, injustices, and possibilities. Nussbaum's cosmopolitan education promotes the understanding that we are all unique, precious, interdependent, and relational beings. As such we need to learn to dialogue and collaborate in order to face the current crisis.

Henry Giroux defines citizenship education as transdisciplinary, relational, holistic, profoundly political, collaborative, and instigative of hope for a better world. The primary focus of citizenship education is in fact to enhance the civic courage by stimulating "students' passions, imaginations, and intellects so that they will be moved to challenge the social, political, and economic forces that weight so heavily upon their lives" (Giroux 1980, 357). Citizenship education is based on critical thinking, social awareness, and action competence. Critical thinking requires challenging the status quo, re-examining old practices, and established beliefs. Social awareness is about developing empathic and social skills to understand the conditions of the Others. Social action means; having the courage to pursue ideas beyond the classroom into the world, being inextricably related to everything within the web of life.

Cosmopolitan citizenship education requires an openness in guaranteeing that all learners have equal access to education (Wink 2000, 71).

Cosmopolitanism and citizenship expand the language of architecture, by encouraging educators and students to be much more than spatial explorers but world citizens architects who are interested in designing how all earthlings can live harmoniously together. Becoming cosmopolitan citizen architects means learning to make ethical design decisions, decisions that are grounded in their social and environmental context and are equally influenced by the understanding of their local and global implications, ultimately, we are all connected as citizens of the world. Architects have a social and ecological responsibility: to design spaces for communities in harmony with the nature, to pursue the spirit of social and environmental justice. With this serving as a theoretical context it is now the time to dialogue directly with the students.

\section{METHODS}

Dialogues are the essence of education: "without dialogue there is no communication, and without communication there can be no true education" (Freire 1993, 66).

During the Fall of 2018 I visited eleven schools of architecture part of the NBAA network and conversed with fourteen students. Students' interviewed were five men and nine women, between 22 and 32 years old, in their 4th and the 5th year of studies. All interviews were semi-structured, initiated by four research questions:

Q1-What skills should students have after studying architecture?

Q2-How should these skills be taught?

Q3-How can the education of an architect be of special importance to our society? 
The questions were designed to be sufficiently “open-ended yet directed, shaped yet emergent, and paced yet unrestricted" (Charmaz 2014, 85). Question number three is a "sensitizing concept" to encourage the interlocutors specifically to reflect on the societal role and responsibility of an architect in our society (Charmaz 2014, 30). All interviews were recorded and transcribed for a total of 8 hours and 43 minutes. All participants received the transcripts and were invited to make comments or amendments if necessary.

On my return to the IUA in January 2019 I continued asking the same questions to my current and future students in forms of group interviews, singular interviews, and workshops. So, the same three questions were asked to a total of thirty-two current students at the IUA and sixty-four perspective students, specifically:

- 34 perspective students in architecture (interviewed May 6th and 7th 2019);

- 30 perspective students in architecture (interviewed May 27th and 28th 2020);

- 21 second year students in architecture at the IUA ,

- 11 International students studying at the IUA during the academic year 2019-2020

All the interviews were analyzed using the abbreviated Constructivist Grounded Theory (CGT) method which helped me examine the data (transcribed interviews) carefully before framing a specific hypothesis (Charmaz 2014). From the data analysis four narrative emerge and describe the role of an architect as a "dissident intellectual", as an "ethical professional", as a "storyteller", and as a "the carer of the world". These four narratives were consistently present in all the answers to the three questions. By listening closely to the students' voices, and their narratives strong connection emerge between them and the understanding of Cosmopolitan Citizenship Architectural Education. The intention of this paper is therefore to show the genesis of this conception by using both literature reviews and students' dialogues.

\section{FINDINGS: FOUR NARRATIVES}

All students interviewed began their answers by recognizing the overwhelming scope of architectural education and questioning it as whether it is doing enough to prepare them to respond to the ecological and social crisis felt to be of paramount importance for the continuation of life on our planet. These fundamental concerns shape students' vision of architectural education to be intended as a social platform for personal growth and critical thinking, for social awareness, and collaboration with other people for a better world. Four fundamental narratives consequently emerge, and they describe the architect as a "dissident intellectual", as an "ethical professional", as a "storyteller", and as a "carer of the world".

These narratives intertwine, overlap and run parallel through the entire conversations with the students. As such they need to be seen relationally, part of the respondents' understanding of their societal role and responsibility and therefore on the role of architecture education. Ultimately the whole findings constitute the foundation to build the conception of Cosmopolitan Citizenship Architecture Education CCAE. 


\subsection{First narrative: The architect as a dissident intellectual}

This narrative is based on understanding the role of architects as people who are critical of the current reality and uses their knowledge and voice for ecological and social amelioration. This resonates tremendously with what educator bell hooks defines a dissident intellectual that is people that "are critical of the status quo and they dare to make their voices heard on behalf of justice" (hooks 2003, 187). Respondents understand that even though architecture has a vivid image is not just a picture to be published in a magazine "Architecture education should not just be about designing beautiful houses it should make us critical" (Student in architecture at Chalmers, Gothenburg, November 14, 2018). This element of criticality of awareness is considered to be a foundation for their education. Students know that architecture education is a lengthy and complex process, nevertheless, they show a surprising optimism firmly believing in the importance of architecture.

Respondents believe that "You can use that kind of process (architectural thinking) in many kinds." (Students in architecture at AAalto, Helsinki, December 11, 2018) since architecture is about making sense of the world, dealing with its complexity, and finding solutions. But to be effective architectural education needs to act as a social platform capable of exposing students to different source of knowledge, learning conditions, experiences, and diverse points of views. Specifically, one student states:

teachers must be different so that they can support the students to find their own voice their own path and in that way they maybe find their voice and then can contribute to the society in some ways, or have an opinion and so on (Aalto, Helsinki December 11, 2018).

Exposing students to diversity of thoughts is key for helping students to find their inner compass, their mastery, for developing the empathy and confidence that is needed to then position themselves as outspoken, critical, socially aware architects - that is to acquire the role of dissident intellectual, of a person that uses architectural thinking for the greater good. A student states: "We are not the same persons, and the school should not produce the same architecture students". (NTNU, Trondheim December 20, 2018). When students feel confident about their skills and optimistic about their future, they also feel liberated and empowered to imagine their many possible roles in the society. And they embrace the diverse possibilities with enthusiasm, as one student states: "This is not the time to be in one cage to decide whether you are a professor or a practitioner, this is the time to be all over the place!!" (RTU, Riga November 29, 2018). There is therefore no singular dominant vision of what and architect should do. Architecture is plural and diverse, and architects will bring their working method, critical collaborative capacities into every task that they are working on.

\subsection{Second narrative: The architect as an ethical professional}

"I look forward to participating in the creation of a more sustainable future" (perspective student in Architecture IUA, Reykjavik May 27, 2020). 
Students are aware of the basic competences that are necessary in order to operate as architects: from having a good spatial understanding to the ability to visualize and test their ideas by using the appropriate software. A student says: "What I think first of all is critical thinking, problem solving, spatial thinking, and basic skills to express your ideas like drawings. One very important thing is to have an opinion and not be afraid of expressing it." (VDA, Vilnius November 22, 2018)

Nevertheless, these competences alone are not enough to form good architects. A student states:

I think that architects should not only have knowledge about using computer skills but also have the understanding of how to make architecture more social and think about other problems which are, I think, something of what we have to consider when we work tomorrow

(VGTU, Vilnius November 27, 2018).

Architects design buildings and processes, and the act of design is about making choices, the impacts of which reverberate in society and beyond. Architect should therefore be aware of their role and responsibility in the society and sensitive to the fact that to every design choice corresponds a social and ecological impact that needs to be understood and evaluated, not just in terms of costs and space but also in terms of its social and ecological value. Designing the right thing is therefore more important than designing the thing right. The latter is focused on the accuracy of the product, while the former is based on critical thinking and reflects its context in the bigger picture. What are the potential social, and environmental effects on this act of designing? What power relations are shifted? What other options are there? What could be the long-term consequences? Who makes the decision? Who builds your architecture? In other words: "What is the story behind a beautiful building?" (Chalmers, Gothenburg November 14, 2018).

Students do not want to be part of a system of ecological and social exploitation but want to operate as a positive, restorative force in their society and, most importantly, they need to believe that what they are doing is the right thing. One student puts in these terms: "I just want to do something that interests me and make some impact, ehm like in a good way, for our environment and society" (Aalto, Helsinki December 11, 2018). Students show empathy, sensibility and courage to operate ethically for the greater good of the society.

\subsection{Third narrative: The architect as a storyteller}

"It does not have to end with an architecture project" (AHO, Oslo November 16, 2018).

This narrative is based on the importance of storytelling. Architects are people that ultimately do not build but coordinate the social processes that are at the base of their work whatever that may be. Communication is fundamental in this collaborative process and architects need to learn how to engage and converse with the world. One student says therefore that: "I think the responsibility of the school is to give the students a way of interacting with life with their field of work" (RTU, Riga November 29, 2018). 
Consilience, i.e. the ability to link together principles and people from different disciplines, is therefore valued as an extremely important quality that an architect should have. As one student explains it: "I think that the most important skill is cooperation and collaboration" (BAS, Bergen November 19, 2018). This quality is fundamental for solving the on-going social and ecological crises. Consilience requires social and collaborative skills to operate as an activist and protector of the common good. It is not just about problem solving but also about revealing important and cogent issues of our times and create sufficient consent and support to be able to tackle them collectively. One student illustrates it as: "to be critical and to be able to work with others, and what I mean with this is the capacity to put your feet in somebody's else shoes, so this is also in terms of empathy" (Chalmers, Gothenburg, November 14, 2018).

Storytelling in this sense then refers to the ability of the architect to understand cogent issues, and to reveal them using architectural thinking and tools (models, diagrams, narration, photography, installations, publications, writings) as vehicles for communication. To help students develop these skills, schools have to become platforms for socialization, allowing different knowledge and experiences to work together, as one student says: "I think everything should be connected" (KADK, Copenhagen, December 22, 2018).

\subsection{Fourth narrative: The architect as a carer of the world}

"I would like to participate in creating and changing the world" (perspective student in Architecture IUA, Reykjavik May 6 2019).

An important aspect that needs to be underlined is that despite the fact that the interviews started with the specific question of Q1-What skills should students have after studying architecture? Students' responses began by illustrating the context of their education in a time of global ecological and social crisis. Respondents position themselves primarily as people who care for the Earth, for the common good "Architecture has an impact on everybody's lives" (KADK, Copenhagen December 22, 2018) "you should really take the environment into consideration in your design" (AALTO, Helsinki December 11, 2018).

The notion of care acts as a lens through which students not only look at the world but also want to act in order to ameliorate it as both professionals and citizens. Respondents show awareness in understanding that architecture can both act as a source for good and amelioration but equally can further contribute to exploitation and ecological destruction. Respondents show skepticism towards big corporative firms, defined as entities which do not care enough, and seems much more inclined to work in their local context with people that they can trust and on projects that they feel passionate about. Working locally does not exclude them to be in contact with the world and use their established networks to collaborate on projects that cross geographical boundaries. "It is not just about the building it is also about the outside world, the streets and the squares, things that are part of your life" (EKA, Tallinn December 3, 2018). 


\section{CONCLUSIONS AND FUTURE WORK}

Respondents depict the multiple roles of architects. Some students want to explore the building side further, some want to explore urban issues, some want to write about architecture, some want to explore the managerial side. For all architecture education is intended as a journey that helps students find their own path and develop as autonomous individuals but equally to form professionals capable to work collaboratively.

To do so architects need to learn to converse with the world, this is intended as the best way to incite their sensitivity and to prompt ethical design solutions. It would be really important to understand whether these traits are specific among students in architecture or whether they are universally shared among students from different disciplines. To answer this question more research needs to take place.

The findings of this research reveal four fundamental roles of an architect in our society: the dissident intellectual, the ethical professional, the storyteller, the carer of the world. A good architectural education should therefore help students to pursue their unique path in architecture for caring of the world.

From the world of education, a person has emerged as leader and catalyst of change. She is a student and her name is Greta Thunberg. Greta simply says that education without a future has no meaning. She has become a leader that brings students and education in the frontline in the quest for a solution to the climate crisis. September 20, 2019 will be remembered as the Global Climate Strike which is said to be the biggest climate protest in world history (Barclay \& Resnick 2019). Students therefore feel that they are not just called into a cause, but they are the promoter of the cause itself. This is the context of this research, of its methods, of its dialogues and findings. Within this context the paper's intention was to provide an interpretative and explanatory framework with which to understand the students' voices, their understanding on what it means to be a student in architecture in the current context. Students from the NBAA capture the essence of their education as a journey to develop critical thinking to acquire social awareness, to instill social activism, to grow.

CCAE can help us answering the questions of how does a good architectural education look like? Educators can teach the right thing when students are allowed to bring their experiential knowledge into the classroom, when educators create the conditions that make students critical and engaged, when educators help students nurturing their individual talents without forgetting that we are all connected and interdependent.

CCAE is intended as a way to develop a more caring and intimate relationship among architects and their community which is based on social awareness and collaboration, driven by the desire to operate with care and social responsibility (Santanicchia, 2019). Becoming cosmopolitan citizen architects means learning to understand the social and environmental impact of design decisions and how those decisions can respond to the cogent issues of our society. This means becoming critical thinkers and outspoken intellectuals, carers of our planet and its earthlings, and stewards for promoting the necessary collaborative change that we need for protecting life on this planet. Architecture education scope goes therefore beyond building's design, it is about how people can live and flourish together in an environment which is always both natural and man-made. 
This requires education to be place-based and socially contextualized. It requires education to cross disciplinary boundaries. It requires education to be generous to welcome people from all walks of life. It requires education to be about the common good and how we live together. And it requires students and teachers to work together, to dialogue to use critical thinking to discover together awareness and activism. It requires the confidence, competence and the art of consilience to be a public intellectual, an ethical professional, a storyteller, and a carer of the world. It requires care and courage.

The teacher said that I had a good spatial sense and he suggested that I could be an architect, I remember my first thought was damn!! It is such a bad profession, I do not know why... but I thought so...

(Student from RTU, Riga November 29, 2018).

\section{ACKNOWLEDGMENTS}

This paper is an edited and updated version of the original one:

Santanicchia, M. (2020). Becoming Citizens Architects: A Reflection on Architectural Education Across the Nordic Baltic Academy of Architecture NBBA: A Students Perspective. In Roth, M. and Cavallo, R. (Eds.), Conference Proceedings: EAAE, The Hidden School Papers (pp. unknown). Delft: TU Delft Open.

\section{REFERENCES}

Barclay, Eliza \& Brian Resnick. "How Big Was the Global Climate Strike? 4 Million People Activists Estimate." Vox, September 22, 2019. https://www.vox.com/energy-andenvironment/2019/9/20/20876143/climate-strike-2019-september-20-crowd-estimate

Charmaz, Kate. 2014. Constructed Grounded Theory. Thousand Oaks: Sage Publications.

Freire, Paulo. 1993. Pedagogy of the Oppressed. London: Penguin Books.

Giroux, Henry. 1980. "Critical Theory and Rationality in Citizenship Education." Curriculum Inquiry, 10, no. 4 (Winter): 329-366.

hooks, bell. 2003. Teaching Community, A Pedagogy of Hope. London: Routledge.

Nussbaum, Martha. 2010. “Patriotism and Cosmopolitanism”. In The Cosmopolitanism Reader, edited by Garrett Wallace Brown \& David Held, 154-162. Cambridge: Polity Press.

Resnick, Elizabeth. ed. 2016. Developing Citizen Designers. New York: Bloomsbury Academic.

Santanicchia, Massimo. 2019. "Becoming Citizen Architects: A Case Study of 'Streets of Reykjavik 2010', a Design Studio at the Iceland University of the Arts”. Building Material 22: 116-136.

Wink, Joan. 2000. Critical Pedagogy: Notes from the Real World. New York: Addison Wesley Longman. 